\title{
Review: Postoperative radiotherapy decreases survival in early-stage non-small-cell lung cancer
}

PORT Meta-analysis Trialists Group. Postoperative radiotherapy in nonsmall-cell lung cancer: systematic review and metamanalysis of individual patient data from nine randomised controlled trials. Lancet. 1998 Jul $25 ; 352: 257-63$.

\section{Question}

In patients with noz-small-cell lung cancer (NSCLC), does the addition of postoperative radiotherapy increase survival?

\section{Data sources}

Studies were identified by searching MEDLINE and CANCERLIT using a modified version of the Cochrane Collaboration optimum search strategy. Hand searches were also done of meeting abstracts, reviews, specialist journals, and book bibliographies. Cancer trial registries were searched, and investigators were contacted.

\section{Study selection}

Studies were selected if they were randomised controlled trials that compared postoperative radiotherapy with no further treatment, the patients had NSCLC and had had complete surgical resection, the method of randomisation was blinded, orthovolt radiation was not used, and recruitment occurred between 1965 and 1995

\section{commentary}

The study from the PORT Meta-analysis Trialists Group is important because it concerns lung cancer, the leading cause of cancer death around the world. It may also help us learn more about the effects of irmadiating the chest in other types of cancer, particularly breast cancer.

Surgery is the mainstay of therapy for early-stage lung cancer, although about $60 \%$ of patents still die of the disease. Because local relapse remains problematic, radiotherapy has been used postoperatively in an attempt to prevent it and to improve survival. This meta-analysis shows, using the techniques employed, that such radiation has had the opposite effect. The hazard ratio for death with radiotherapy was increased (by $21 \%$ ), equivalent to a reduction
Data extraction

Patient data were obtained from trial in vestigators on survival, recurrence, follow-up, treatment allocation, date of randomisation, age, sex, histological cell type, tumour stage, and performance status.

\section{Main results}

9 randomised controlled trials (2128 patients) were included; 3 trials were unpublished. Doses of postoperative radiotherapy ranged from 30 to $60 \mathrm{~Gy}$, given in 10 to 30 fractions. No evidence existed for heterogeneity among trials. Overall survival was greater in patients who received surgery alone $(P=0.001)$ (Table). The hazard ratio for death with postoperative radiotherapy was 1.21 (95\% CI 1.08 to 1.34). Overall recurrence-free survival was also greater for sturgery alone $(P=0.018$ ) (Table). The hazard ratio for local or distant recur: rence or death was 1.13 (CI 1.02 to 1.26). Subgroup analyses showed that postoperative radiotherapy was more detrimental to survival among patiens with earlier-stage disease ( $P$ for trend $<0.001$ ) and lower nodal statas ( $P$ for trend $=0.016$ ).

\section{Conclusion}

Postoperative radiotherapy in patients with resected non-smail-cell hung cancer adversely affects overal and recurrencefree survival, paticularly for patients with stage 1 or stage 2 disease.

Source of funding: U.K. National Health Serwi Researb and Dealopment Canter Progrmmit

For correspondence: Dr. L.A. Stewart, MRC Cancer Trials Office, 5 Sbaftesbury Ront. Camblidge CB2 2BW, England, UK PAL 44-1223-311844.

Postoperative radiotherapy vs surgery alone at 2 years for non-small-cell lung cancer ${ }^{*}$

\begin{tabular}{lcccc}
\hline Outcomes & \multicolumn{2}{c}{ Weighted event rates } & RRT (95\% CD) & NNH (C) \\
\cline { 2 - 5 } & $\begin{array}{c}\text { Postoperative } \\
\text { radiotherapy }\end{array}$ & $\begin{array}{c}\text { Surgery } \\
\text { alone }\end{array}$ & & \\
\hline $\begin{array}{l}\text { Death } \\
\text { Recurrence or } \\
\text { death }\end{array}$ & $52 \%$ & $45 \%$ & $16 \%(7$ to 22$)$ & $14(10$ to 33$)$ \\
\hline
\end{tabular}

*Abbreviations defined in Glossary; RRI, NNH, and CI calculations based on time-toevent data supplied by author.

in absolute survival from $55 \%$ to $48 \%$ at 2 years.

Based on the data provided, the increase in deaths associated with radiotherapy appears to be related to causes other than cancer. Data from randomised trials of radical surgery with or whout radiation for breast cancer and rectal cancer also show a small but real excess of deaths not caused by cancer in the radiation groups $(1,2 ;$ R. Gray. Personal communication). In these studies the magnitude of the risk is not as great as it this meta-analysis, but undoubtedly a small excess of deathis is caused by the radiation. The larger risk seen in this meta-analysis may be related to acute or delayed radiation effect on the lungs or heart in patients with premorbid disease secondary to smoking or surgery.
Conventional postoperative radiationcen no longer be recommended as routis? therapy in lung cancer. If new therapente approaches are to be tested, they should te done in large randomised controlled trials The fact that only 2000 patients were cruited for these trials over 3 decades, when there were about $20 \mathrm{million}$ deachs from this disease, is a strong indictment of our fallute to test therapies adequately in lung cancer. Chris 7. Willinoss, oll Insitute of Healdh Strint Oxford, Englam, on

References
1 . Cuzick J, Stewart H, Rutquist L, a d ) Clin Oncol. 1994;12:447-53.

2. Early Breast Cancer Trialists' Group N Engl j Med. 1995;33:1444-55. 